\title{
A Comparative Analysis of the Levels of Collective Trust among the Banking Staff in Poland and Russia
}

\author{
Vladimir Aleksandrovich Davydenko \\ Financial-Economic Institute, Tyumen State University, Russia \\ vlad_davidenko@mail.ru \\ Jerzy Kaźmierczyk \\ Tyumen State University, Russia \\ Poznan University of Economics and Business, Poland \\ jerzy.kazmierczyk@ue.poznan.pl

\section{Gulnara Fatykhovna Romashkina} \\ Department of Mathematical Methods, Information Technologies and \\ Management Systems in the Economy, Tyumen State University, Russia \\ g.f.romashkina@utmn.ru

\section{Elena Vladimirovna Andrianova} \\ Department of General and Economic Sociology, Tyumen State University, \\ Russia \\ e.v.andrianova@utmn.ru
}

\begin{abstract}
This article aims to analyze the levels of collective trust in banks in Poland and Russia. These are post-socialist countries and emerging markets and yet there are large discrepancies in the mentality of the respective labour markets. The hypothesis is that collective trust in banks in Russia is lower than in Poland. This has to do with the high level of declarative trust proclaimed by the Russian employees. Moreover, trust is inversely proportional to the level of education. 1,920 bank employees were surveyed in
\end{abstract}

* The study was sponsored by RGNF (Russian Humanitarian Science Foundation). Project: "Capabilities and restrictions of new industrialization and contradictions of sociocultural space: on Tyumen region example", No. 16-03-0050o. Tyumen State University.

(C) VLADIMIR DAVYDENKO, JERZY KAŹMIERCZYK, GULNARA ROMASHKINA \& ELENA ANDRIANOVA, 2018 | DOI:10.1163/15691330-12341462 | This is an open access article distributed under the terms of the prevailing CC-BY-NC license at the time of publication. 
Poland and 359 in Russia. Then the overall indexes of trust in banks and sub-indexes (loyalty; care; openness; dyadic trust; honesty/fairness; common values; appreciation; job security) were calculated.

\section{Keywords}

trust - banks - banking staff - Poland - Russia

\section{JEL Codes}

$\mathrm{P}_{250}-\mathrm{Z}_{130}-\mathrm{O}_{170}$

\section{$1 \quad$ Introduction}

"Collective trust" is an important aspect of human life (Bachmann and Zaheer 2006; Bromiley and Cummings 1995; Hardin 2002; Kramer, Brewer and Hanna 1996; Lane and Bachmann 1998; Lewicki and Bunker 1995; Zucker 1986). The issue of trust is all the more topical because empirical research confirms the erosion of trust in business relationships (Fukuyama 2003). Researchers (Taškar Beloglavec and Šebjan 2015) have examined the influence of education on trust in the banking system. According to the theory, employee trust is a very significant factor, which leads to the success of the entire organization and it is closely related with many aspects of labour, i.e. the incentive system in a workplace.

This paper examines the diversity of trust from the perspective of bank employees in Poland and Russia. Many sectors exert a big impact on the Polish and Russian economy, but the banking sector plays a crucial role in the development of the countries' economy. Banks are 'the bloodstream' of the economy, delivering money to producers and consumers. Moreover, banks employ a huge number of specialists in various areas associated with diverse tasks. The banking sector is also the one that introduces many new technological and organizational changes. Many solutions adopted in foreign mother banks have also been implemented in Poland (Kaźmierczyk 2011).

The main aim of this paper is to measure collective trust levels in banks and compare its levels in Poland and Russia. There are few precise methods of measuring the level of collective trust in the literature. The available tools are based on expressing opinions on the behavior of organizations generally represented 
by most employees. It must be stressed that trust is not measured frequently in organizations. This article not only presents the determinants of trust but also identifies its manifestations in an organization.

The following theses are propounded in this paper:

1. Trust placed in bank employees is largely a noncommittal declaration and as such is tainted with exaggeration.

2. Collective trust levels in banks in Poland is higher than in Russia.

3. With the increasing level of education, collective trust in banks decreases.

To accomplish the research aim the authors used source literature in English, Polish and Russian on sociology, economics, human resource management, banking and industrial and organizational psychology (EBSCO, The АCM Digital Library, BazEkon, Emerald, ProQuest). A survey of nearly 2,00o bank employees in Poland and 359 bank employees in Russia was also carried out.

Following the introduction, this paper includes a brief analysis of trust in banks followed by the formulation of the thesis. Then the research sample and the method adopted are described. Finally, the research results and conclusions are presented.

\section{$2 \quad$ Trust as a Concept with Practical Relevance}

In economics and the social sciences, trust and its functional features, its forms and manifestations, its role as a mechanism of risk reduction in conditions of uncertainty, its cognitive and activity aspects are widely considered (McClellan 2014; Wyrwa 2014). One creates and uses statistics of ratings and monitoring, the measurement results of the levels of various types of trust as a dynamic and functioning phenomenon.

The theory of economics and sociology proposes various kinds of trust: personal (interpersonal), impersonal (abstract), network, systemic, 'acting', and many others. As pointed out by P. Sztompka, acting in conditions of uncertainty and the lack of control, we risk, we stake on something, we take the pledge on the uncertain, independent future actions of other people. Thus, we arrive at a simple, most general definition of trust: trust is a loan that we take out against other people's uncertain future actions. In this understanding, trust includes two elements: confidence and its expression in practice (2012).

The fundamental problem of the essence and content of trust and mistrust/distrust, their correlation and deep meanings is raised by many authors in various fields. Among the various interpretations of the category of trust, 
the following are prominent: trust as part of the theory of structure (Giddens 2003), reflexive modernization (Beck, Giddens and Lash 1994), systems theory (Luhmann 2012), rational choice theory (Coleman 1992). The phenomenon of trust is described from the point of view of the criteria and indicators of an individual's reliability, the social health indicator (Fukuyama 1996), the balance between social roles (Seligman 1997), or a person's maturity, readiness to accept responsibility for one's actions.

P. Sztompka has also developed the notion of 'the culture of trust', which is an important condition for the development of society, business, civil institutions and for the implementation of decisions taken by the authorities. A low level of trust can become a factor that causes conflict. Thus, behavioral trust strategies can be reckless, bordering on 'blind trust', and relying fully on expert systems. The same culture of trust or distrust can be characteristic of banks (Wieczorek-Szymańska 2016:161-171).

It should be noted that in the source literature published after 2010, the interpretation of trust is primarily of an applied nature. Its importance in various spheres and the development of trust in various organizational contexts are studied (Bhati and De Zoysa 2013; McClellan 2014). In Australia, psychological studies on trust development in the banking system and among banking staff based on the R. Lewicki and B. Bunker's model, as well as the development of Lewicki et al.'s model led to a significant correction of the concept of trust development stages. In classical models, trust relationships can begin almost from scratch in a situation where interacting actors consider their interest in trust and calculate the possibility of relations based on trust. R.J. Lewicki, E.C. Tomlinson and N. Gillespie, amend this approach, showing that in some cases the emergence of trust relationships is situationally conditioned, and the development of trust can be based on previous experience of teamwork and on the propensity for trust. In addition, knowing a person is not enough to predict his or her behavior and to build trust on it (2006). S. Bhati and A. De Zoysa complement the above-mentioned interpretation with the need to learn more about the other person in the course of professional interaction, social interactions, and to take into account the views of colleagues about the object of trust (2013).

Collective trust arises when there are appropriate institutional, social and psychological elements in the organization. Collective trust is a tipping-point psychological phenomenon: when enough reassuring factors are perceived as to be in place, collective trust tends to be present. There are many configurations of such factors, but it is assumed that some threshold of such confluent factors is needed to persuade a typical (prototypic) organizational member to trust others (Kramer 2010). 
Instead of individualizing knowledge about specific other people, collective trust is based on schematic knowledge and stereotyped beliefs about the organization and the fact that membership in it tells us about the motives, intentions and likely actions of other members. In this respect, collective trust is viewed as a cognitive construct. Thus, we arrive at the definition of the second basic element of our study, namely the cognitive unit. It is a larger social aggregate, defined and limited by common membership in the organization (Kramer 2010).

To assess the sustainability of an organization, it is important to know the positive expectations people have of others. Positive expectations promote positive behavioral responses when one interacts with other members of an organization. These behaviours, in turn, strengthen the positive expectations and therefore reinforce a virtuous cycle in which the expectation and action are reduced to the creation and strengthening of the desired results (Fukuyama 1996). Individual expectations of reliable behaviour, as suggested by Boyle and Bonacich (1970), tend to change in the direction of the experience, and to an extent proportional to the difference between this experience and initial expectations. Identifying the cyclical and essentially self-reinforcing nature of these vital relationships, (Putnam, Leonardi and Nanetti 1993: 171) noted that "the higher the level of trust within the community, the greater the likelihood of cooperation and cooperation itself generates trust."

\section{Trust - A Hypothesis to Be Tested}

\section{Trust Placed in Bank Employees is Largely a Noncommittal \\ Declaration and as Such is Tainted with Exaggeration}

A comprehensive overview of the source literature shows that no research has been conducted as yet regarding collective trust in Poland and Russia. For this reason, the empirical analysis has to be based partly on an analogy to other kinds of trust in these two countries. Declarative trust is relatively high in Russia because the majority of Russians prefer to be 'like everyone else', not to stand out, and this is a typical trait of the Russian national character. This is reflected in the trust ratings of the Russian president V. Putin, which rose to $52.5 \%$ at the end of October 2017. At the same time the indicator of approval of the president fetched $83.5 \%$. Such data is provided by the All-Russian Center for the Study of Public Opinion. Moreover, president B. Yeltsin's trust rating was $3 \%$ in 1996 (just above the level of statistical error), but then the liberals Y. Gaidar and A. Chubais managed to launch the election campaign (VCIOM 2017). This proves that Russians can quickly change their opinions. 
The hypotheses propounded here concern two types of capital in an organization. Trust is an element of social capital (social relations) and is directly tied to human capital (education). In a situation where a high level of institutional trust is accompanied by a low level of personal trust, the society cannot function autonomously, and depends almost completely on power. This is the current situation in Russia (Sasaki, Latov, Romashkina and Davydenko 2010; Anikin 2017).

\section{Collective Trust Levels in Banks in Poland is Higher than in Russia}

According to many sources, Russia is characterized by a low level of trust. Companies operating in Russia must develop the stakeholders' trust very carefully. Moreover, local level interest groups are weak. Legislation and regulations affect everyday business and life, making it more complicated, which is not conducive to developing trust in businessmen and bank employees. As S. Nysten-Haarala argues, Russia is facing the challenge of both constructing new formal institutions and managing the effects of globalization, which is not helpful in building up trust (Nysten-Haarala and Soili 2013; Radaev 2005).

Why is the system trust in Russia at such a low level? According to G. Hosking, who carried out a comparative analysis of trust in Russia and in the UK (2012), currently most Russians live in conditions in which they can no longer trust their currency, the state, the police or other social institutions (Sasaki and Marsh 2012).

A similar situation was observed in Poland at the beginning of the economic transformation at the turn of the 199os. The general trust in public institutions was very low. Changes in the economy and society, massive unemployment in the first years of capitalism did not lead to an increase in trust. However, the following decade brought about some changes in this area. A steady increase in the general trust in strangers and a slow one in public institutions were observed (Latusek and Cook 2012; Wciórka 2008).

One might attempt to assess the current level of trust on the basis of the current GDP growth. As noted by S. Knack and P. Keefer, in a number of countries a positive correlation has been observed between the share of trusting people and the GDP growth (1997). Poland, thanks to the European structural and investment funds and its membership in the Schengen Area, is currently experiencing rapid economic growth. The unemployment rate has reached its all-time low of about $6 \%$ since the beginning of the socio-economic transformation in 1990 (GUS 2017). Russia, on the other hand, is struggling with low oil prices, high euro and dollar exchange rates, still relatively high inflation and the consequences of restrictions imposed by Western countries (Markets Insider 2016; Koshkin and Zubacheva 2016). This suggests that interpersonal 
trust should be at a higher level in Poland than in Russia. However, the way this interpersonal trust is transformed into collective forms of trust (for example, trust in an organization) still remains unexplored.

\section{With the Increasing Level of Education, Collective Trust in Banks Decreases}

The influence of a person's educational level of trust has not been researched in detail yet. The research by S. Taškar Beloglavec and U. Šebjan concerning the level of trust of bank clients demonstrated that the customers with secondary education are more likely to place trust in banks in times of crisis than those with tertiary education (2015). Moreover, people with a university degree are more intelligent in general, and as such are more aware of a wide range of possible unfair actions that can be performed in the environment. All in all, the issue of collective trust as related to one's level of education is not clear-cut.

\section{$4 \quad$ Data $^{1}$}

The questionnaire consisted of an introduction followed by 23 closed-ended questions and several demographic and work-related questions. The main part of the questionnaire contained questions which refer to several important human resource management areas (recruitment, forms of employment, motivation, professional education, e-learning, loyalty, stress, work efficiency, мвоs, perks, mobbing, professional career, derecruitment, dismissals and outplacement). Some of the questions were used to test the research thesis.

The data from the survey, which was conducted in Poland between January 2016 and April 2016 and in Russia (the Tyumen region) between February 2017 and April 2017, were used to test the research thesis. Personal contacts and individual visits to banks were used to collect the data. In Poland, more than 20,000 requests, whereas in Russia more than 4,000 queries were sent asking to fill in the questionnaire via e-mail, social networking websites (such as GoldenLine and LinkedIn) and thematic forums. Both an electronic version and a hard copy of the questionnaire were used in the survey.

The main survey was preceded by a two-stage pilot survey in Poland (18o students and 100 employees from banks). Then, the survey was translated into Russian by a group of 12 philologists, psychologists, bankers and HRM

1 The research results presented are part of a broader study. Thus, the description of the research method is applicable also to the results of research on other aspects of HRM and other papers by the authors. You can find more detailed data in our previous papers. 
TABLE 1 The component matrix of the general index of collective trust and its subindexes (Mann-Whitney test) for Poland and Russia

Exploratory factor analysis

$\begin{array}{lll}\text { Component } 1 & \text { Component } 1 & \text { Component } 1 \\ (\mathbf{P L}+\mathrm{RU}) & (\mathrm{PL}) & (\mathrm{RU})\end{array}$

\begin{tabular}{llll}
\hline Honesty/fairness & 0.841 & 0.850 & 0.814 \\
Care & 0.816 & 0.815 & 0.822 \\
Openness & 0.815 & 0.805 & 0.820 \\
$\begin{array}{l}\text { Dyadic trust (a direct question } \\
\text { about trust) }\end{array}$ & 0.793 & 0.793 & 0.782 \\
Appreciation & & & \\
Job security & 0.779 & 0.775 & 0.701 \\
Common values & 0.739 & 0.722 & 0.747 \\
Loyalty & 0.734 & 0.716 & 0.746 \\
& 0.623 & 0.595 & 0.620
\end{tabular}

SOURCE: OWN COMPUTATIONS BASED ON THE SURVEY DATA.

specialists. The two-stage study in Russia was conducted (50 students and 50 bankers). The final research sample consists of 1,920 respondents ( 152 electronic version and 1,768 hard copy) in Poland and 359 respondents (hard copy) in Russia.

The composition of the research sample according to gender, the type of education and the type of bank corresponds to the structure of employment in the banking sector in Poland (Kaźmierczyk 2011). The mean age of the respondents was 36.6 years in Poland and 31.7 in Russia. The mean work experience in banking was 7.8 years, ranging from o to 38 in Russia; in Poland the mean work experience in banking was 12.065 years, ranging from 1 to 43 years. The mean total work experience of the respondents was 15.0 years in Poland and 11.2 in Russia.

\section{$5 \quad$ Collective Trust: Empirical Research}

In the analysis, we rely on a cognitive unit of collective trust, which is a larger social aggregate, defined and limited by the common membership in an 


\section{Mann-Whitney test}

\begin{tabular}{|c|c|c|c|c|c|}
\hline $\begin{array}{l}\text { Subindexes } \\
\text { values } \\
\text { (PL) }\end{array}$ & $\begin{array}{l}\text { Subindexes } \\
\text { values } \\
(\mathrm{RU})\end{array}$ & $\begin{array}{l}\text { U Mann- } \\
\text { Whitney } \\
\text { Statistics }\end{array}$ & $\begin{array}{l}\text { WWilcoxon } \\
\text { Statistics }\end{array}$ & $\mathrm{Z}$ & $\begin{array}{l}\text { Asymptotic } \\
\text { significance } \\
\text { (two-tailed) }\end{array}$ \\
\hline 2.33 & 2.59 & 281999 & 2112740 & $-5 \cdot 40$ & $<0.001$ \\
\hline 2.57 & 2.94 & 269249 & 2096165,5 & -6.56 & $<0.001$ \\
\hline 2.29 & 2.72 & 235474 & 2073877 & $-9 \cdot 53$ & $<0.001$ \\
\hline 2.61 & 3.01 & 267084,5 & 2055970,5 & $-6.5^{0}$ & $<0.001$ \\
\hline 2.50 & 3.13 & 176371 & 2010941 & -14.73 & $<0.001$ \\
\hline 2.31 & 2.72 & 226572,5 & 2061142,5 & -10.27 & $<0.001$ \\
\hline 2.38 & 2.89 & 223139 & 2055794 & -10.55 & $<0.001$ \\
\hline 1.90 & 1.96 & 192310 & 1858535 & -11.10 & $<0.001$ \\
\hline
\end{tabular}

organization. In order to measure trust level in banks, a questionnaire was used which covered various aspects of human resources management. For the empirical analysis, such aspects have been selected that broadly characterize the various aspects of trust in bank employees. Trust is influenced and accompanied by many different factors, whose contribution to the building up of trust can be different in a specific context.

The exploratory factor analysis (EFA) was performed to confirm the quality of the calculated trust indexes for Poland and Russia together and for both countries separately (principal component analysis, PCA). The total variance explained was $59.3 \%$ for both countries together, with $57.6 \%$ for Russia and $58.2 \%$ for Poland respectively. All the data used in the exploratory factor analysis yielded one component with high correlations (Table 1). This was confirmed by a screen plot, which also pointed to one component (both in Poland and Russia).

The general index of trust ${ }^{2}$ and its subindexes were calculated. All subindexes were weighed equally when calculating the overall index of trust. It has been assumed that all of the aspects (subindexes) positively correlate with the

2 The job security index was calculated on the basis of (O'Neill and Sevastos 2013). 
general trust index. The subindexes included: ${ }^{3}$ loyalty; care; openness; dyadic trust (a direct question about trust); honesty/fairness; common values; appreciation; job security. The particular subindexes have been decoded in the Appendix.

As regards to Poland, the following components proved to be the most important for the general index of trust: honesty/fairness, care and openness. Exactly the same components were important for Russian bank employees, yet their order was different: care ranked first, followed by openness and honesty/fairness. Loyalty, in turn, correlated least with the overall trust index for both countries. The identical structure of the main factors for both Russia and Poland indicates a high level of generality of the obtained results. It can be concluded that banks in both countries operate in a similar way and people react in a comparable way to the management tools.

However, the social context in which collective trust is formed in the banks of Russia and Poland is not the same. A higher level of the Collective Trust Index in Russia is ensured by the large contribution of the subindexes of loyalty, common values, and job security. In Polish banks, on the other hand, a greater contribution of the subindexes of honesty/fairness, dyadic trust, and appreciation has been observed.

One may conclude that in Poland the structure of trust is mostly formed by impersonal or generalized judgments about honesty/fairness, care and support. In contrast, in Russia collective trust is formed mostly on the basis of management support (caring), openness to dialogue, only then to be followed by generalized judgments about honesty and justice. It can be assumed that the management of collective trust in Russian banks should be based on a demonstration of care and openness, whereas in Poland, it can be managed on the basis of due consideration given to the integrity and fairness of social communication.

\section{Trust Placed in Bank Employees is Largely a Noncommittal Declaration and as Such is Tainted with Exaggeration}

The values of the subindexes were compared and so was the direct trust question included in the main Trust Index. It was assumed that if the mean value

3 All these aspects and their impact on the level of trust were studied by (Lane 2013; Brock 1998; White 1998; Noddings 2012; Sheresheva, Berezka and Yakuba 2016; Yıldız and Bürüngüz 2013; Thomas, Zolin and Hartman 2009; Chan 2007; Perry and Mankin 2007; Goold, Fessler and Moyer 2006; Buta 2016; Brányi and Józsa 2015; Ding May-Ching, Ho Ching Wei and Lii YuanShuh 2016; Okello and Gilson 2015; Mianowska 2017; White 2014; Sora, Cuyper, Caballer, Peiró and Witte 2013; Arnold and Staffelbach 2012). 
of the answer to the direct question was significantly higher than the value of the subindexes, it would follow that the declarative trust is higher than the trust measured by more objective indicators. Comparisons were made for both Poland and Russia. The thesis has been confirmed for both countries. In the case of Poland, the average value of the answer to the direct trust question was higher than the value of each subindex that measured the trust indirectly (Table 1). The total average value of all subindexes (excluding the direct question) was 2.28 for Poland, while the declared value of trust was 2.61. Similar results were obtained for Russia. The direct trust response was 3.01, while the average Trust Index for Russia (excluding the direct question) was 2.71. As regards to Russia, the only subindex that was slightly higher than the value of the answer to the direct trust question was Appreciation (3.13).

Russia is characterized by high declarative trust. However, as a result of Russian banks being revoked banking licences, employees are afraid of losing their jobs, feel insecure about their social security and therefore they answer questions concerning trust excessively high. This has been proved by the results of this research. Similar results for Poland suggest that Poles are also afraid of being made redundant. The society is not yet mature enough to express their views and opinions about their employment and colleagues. Employees who declare a high level of trust do so only to be in the employer's good books.

\section{Collective Trust Levels in Banks in Poland is Higher than in Russia}

Contrary to the assumption propounded by the second hypothesis, namely that trust in banks in Poland is higher than in Russia, ${ }^{4}$ it turned out that collective trust in Poland is lower (2.33) than in Russia (2.75). The difference between the Russian sample and the Polish one is statistically significant in relation to middle-level managerial positions $($ Figure 1$)($ Russia $=2.98$, Poland $=$ 2.48; Mann-Whitney test: $\mathrm{U}=1074.5 ; \mathrm{W}=9459.5 ; \mathrm{Z}=-4.2 ; \mathrm{p}=0.000$ ), lowerlevel managerial positions (Russia $=2.71$, Poland $=2.41$; Mann-Whitney test: $\mathrm{U}=1373.0 ; \mathrm{W}=13001.0 ; \mathrm{Z}=-2.5 ; \mathrm{p}=0.013)$ and non-managerial positions (Russia $=2.71$, Poland $=2.29 ;$ Mann-Whitney test: $\mathrm{U}=110583.0 ; \mathrm{W}=1213938.0$; $\mathrm{Z}=-9.8 ; \mathrm{p}=0.000$ ). The strength of the difference (an effect size, Glass rank coefficient) between Russia and Poland is of medium value (respectively 0.48 ;

4 The indexes do not follow normal distribution (Kolmogorov-Smirnov test): general index of trust in both countries combined (arithmetic mean $=2.39$, standard deviation $=0.65$, test statistics $=0.026$, asymptotic significance $($ two-tailed $)=0.001)$; general index of trust in Russia (arithmetic mean $=2.75$, standard deviation $=0.59$, test statistics $=0.05^{2}$, asymptotic significance $($ two-tailed $)=0.023$ ); general index of trust in Poland (arithmetic mean $=2.33$, standard deviation $=0.64$, test statistics $=0.026$, asymptotic significance $($ two-tailed $)=0.005)$. 


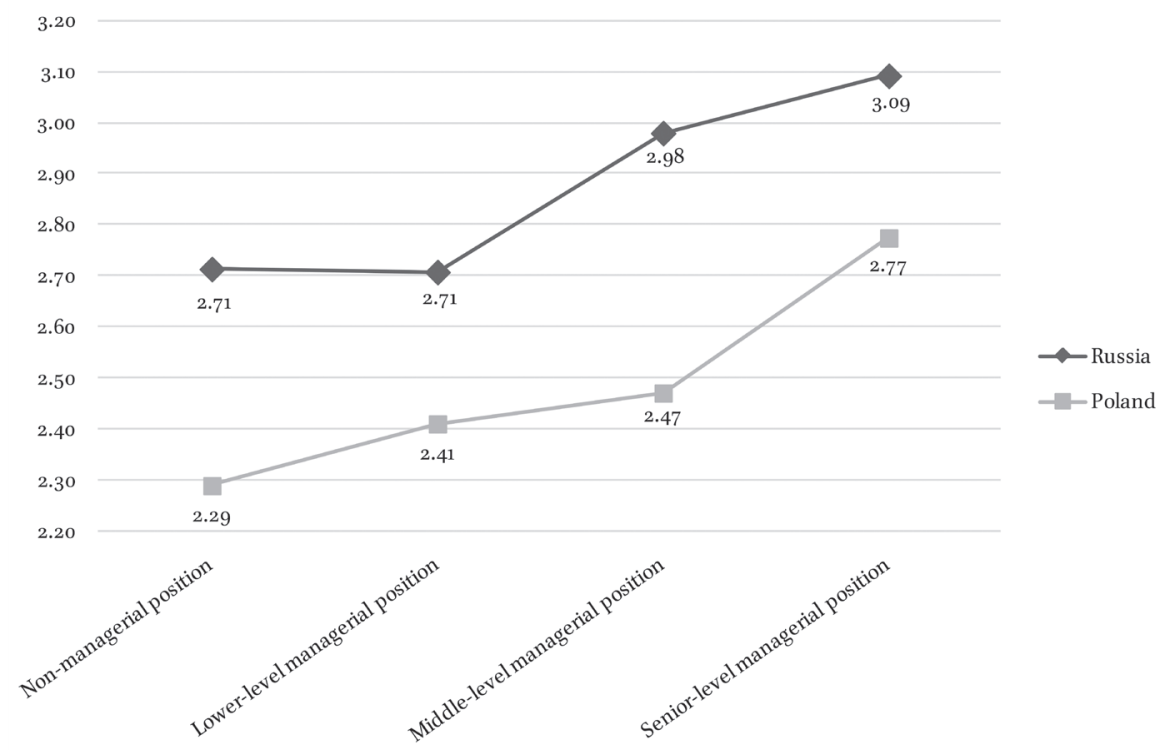

FIGU RE 1 Collective Trust Index in Russia and Poland by the occupied position. OWN COMPUTATIONS BASED ON THE SURVEY DATA.

0.31; 0.39). The difference between the Russian Federation and Poland is not statistically significant in relation to top management (Mann-Whitney test: $U$ $=32.0 ; \mathrm{W}=978.0 ; \mathrm{Z}=-0.6 ; \mathrm{p}=0.545)$, which is probably due to a small sample concerning senior management staff.

The results confirm that in Poland collective trust levels are lower than in Russia. Even though Russia ranks last in many trust rankings, the level of collective trust in Poland is even lower. ${ }^{5}$ Poland is characterized by a different level of economic and social development than Russia. Its economy is more open than the Russian economy and therefore in Poland the globalization processes, such as consumerism, are more common. On the one hand, due to the impact of almost 50 years of socialism in Poland, the capitalist principles of generalized trust did not have the chance to take root. These principles are usually worked out and passed down from generation to generation. Socialism did not allow the Poland to develop into a full-fledged civil society. A similar situation can

5 Russia (37 points) and Poland (35 points) occupy the last two places in the Edelman Trust Barometer 2014. By comparison, the average global European rating was 54 points (Edelman Trust Barometer 2014). 
also be observed in Russia, but it is the Polish society that seems to be closer to the principles of individualism and consumerism that the Poles have adopted from the contemporary capitalist system. Both Poles and Russians trust a narrow circle of people, most often their families and (to a lesser extent) closest friends. However, people in the immediate environment are lacking in mutual trust of the kind that can be observed in other societies. The lack of generalized trust (which has higher levels of abstraction) manifests itself in the need for control, so common in Russia: countless documents, certificates and 'spravki' required not only from the borrowers but also from employees. This stresses the importance of generalized trust as a cost-reducer for businesses and the national economy as such.

\section{With the Increasing Level of Education, Collective Trust in Banks Decreases}

The study has shown no statistical difference in collective trust according to the level of education (in both countries taken together and in either country respectively) (Table 2). Collective trust is not affected by education and this holds true both for the non-managerial and the managerial group. Most of the banking staff in Poland and Russia have higher education (often in Economics or Management), which could have had a significant impact on the obtained results. Therefore, a division has been made into employees with tertiary economic education and those with other kinds of education. As it turned out, no difference in trust levels was observed within these groups (Russia: University economic education $=2.73$, Other kind of education $=2.81$, Mann-Whitney test: $\mathrm{U}=10153.5 ; \mathrm{W}=33589.5 ; \mathrm{Z}=-1.521 ; \mathrm{p}=0.128$; Poland: University economic education $=2.32$, Other kind of education $=2.34$, Mann-Whitney test: $\mathrm{U}=424488.5$; $\mathrm{W}=813891.5 ; \mathrm{Z}=-0.589 ; \mathrm{p}=0.556)$.

\section{Conclusions}

Collective trust in an organization is directly related to the realization of the common fate, shared social identities in the organization, its history and the organizational settings (the situation in the organization). These concepts include, for example, the study of the grounds for collective trust in various staterun institutions and private organizations, including banks.

This comparative study is the first that investigates the differences in collective trust levels that was carried out on a sample of Polish and Russian bank employees and took into account the declarative trust and the level of education. Trust as a complex construct constitutes an interesting research field, 
TABLE 2 Collective trust levels in banks by different levels of education (Kruskal Wallis H test)

\begin{tabular}{llll}
\hline & $\begin{array}{l}\text { General } \\
\text { secondary } \\
\text { education }\end{array}$ & $\begin{array}{l}\text { Secondary } \\
\text { vocational } \\
\text { education }\end{array}$ & $\begin{array}{l}\text { Secondary } \\
\text { education in } \\
\text { another field }\end{array}$ \\
& & & \\
\hline Russia & 3.09 & 2.67 & - \\
Poland & 2.20 & 1.55 & 2.39 \\
Senior managerial position & - & - & 2.79 \\
Middle-level managerial position & - & - & 2.73 \\
Lower-level managerial position & - & - & 2.62 \\
Non-managerial position & 2.87 & 2.27 & 2.35 \\
& & & \\
\hline
\end{tabular}

SOURCE: OWN COMPUTATIONS BASED ON THE SURVEY DATA.

especially for those who deal with the problem of relational orientation in management.

In conclusion, it is worth stressing that the development of collective trustrelated issues in management sciences is an important element of contemporary knowledge on the functioning of people. The issue of intra-organizational trust is one of the unexplored areas in trust research that requires further studying. Collective trust in banks is very rarely examined. Banks guard access to their employees justifying this by banking secrecy. They suggest that outsiders can, in the course of their research, disturb the valuable but potentially fragile balance between trust in general and the collective forms of trust. In fact, it has often to do with internal and external public relations. Banks sometimes conduct surveys of employees' opinions; however, the questions regarding collective trust play a marginal role. Despite this, we managed to conduct a large survey both in Poland and Russia. Moreover, in our study we proposed a new methodology of measuring collective trust. The question is how to test the level of trust between employees in order to obtain the most reliable results possible and overcome the inadequacy of declarative responses. The separation of the collective trust sub-indexes and the comparison of the sub-index results with the findings obtained in answer to the direct question concerning the level of trust make the employees' answers reliable. The method of measuring collective trust applied in this analysis proved effective and allows one to draw valid conclusions. We applied a new methodological approach and compared the answers to the direct question regarding dyadic trust with the 


\begin{tabular}{llllll}
$\begin{array}{l}\text { Secondary } \\
\text { education in } \\
\text { the economic } \\
\text { field }\end{array}$ & $\begin{array}{l}\text { University } \\
\text { education in } \\
\text { another field }\end{array}$ & $\begin{array}{l}\text { University } \\
\text { economic } \\
\text { education }\end{array}$ & Test statistic & df & $\begin{array}{l}\text { Significance } \\
\text { two-tailed }\end{array}$ \\
\hline 2.64 & 2.82 & 2.73 & 5.102 & 4 & 0.277 \\
2.34 & 2.32 & 2.32 & 3.837 & 5 & 0.573 \\
2.66 & 2.73 & 2.81 & 0.685 & 3 & 0.877 \\
2.41 & 2.49 & 2.62 & 2.212 & 3 & 0.530 \\
2.61 & 2.51 & 2.40 & 2.010 & 3 & 0.570 \\
2.33 & 2.37 & 2.35 & 2.306 & 5 & 0.805
\end{tabular}

values of subindexes relating to a variety of areas in which collective trust was measured. The thesis has been confirmed for both countries - trust placed in bank employees is largely a noncommittal declaration and as such is tainted with exaggeration.

A high level of collective trust is the starting point for implementing various methods and techniques of management. The same is true for trust management. One can even say that its place is central to other management concepts. Contrary to common expectations, it turns out that the level of collective trust in banks in Russia is higher than in Poland. This can be attributed to the overall low level of trust in both countries as illustrated by a variety of papers. This may be due to the countries' common history, burdened with the era of socialism, which not only influenced labour productivity and the standard of living but also collective relations. Considering that Poland is at a slightly more developed and globalized country, one can assume that the level of trust in Russia will continue to fall in the future. The characteristics of the Russian society are also conducive to this. The levels of collective trust in groups with different levels of education were similar. This may result from the employment structure in banks, most of the employees having a university degree.

It would also be interesting to analyze the impact of foreign capital in the banking sector on the level of trust in banks. Russia is characterized by a relatively small share of foreign capital in the banking sector, but in Poland over $50 \%$ of bank equity is foreign-controlled. It is also worth looking into the question of how the transfer of management know-how from foreign mother banks affects collective trust levels in banks. The results confirm the need for banks 
to build trust-based teams and therefore such factors as the composition of teams, the nature of their work and the organizational context need examining. Finally, lack of trust is a symptom of something else. Apparently, bankers do not think that trusting others is worth it.

\section{References}

Anikin, V. 2017. "Human Capital: Genesis of Basic Concepts and Interpretations." Journal of Economic Sociology 18(3): 120-156.

Arnold, A., Staffelbach, B. 2012. "Perceived Post-restructuring Job Insecurity: The Impact of Employees' Trust in one's Employer and Perceived Employability." Zeitschrift Für Personalforschung 26(4): 307-330.

Bachmann, R. and Zaheer, A. 2006. Handbook of Trust Research. Northampton: Edward Elgar.

Beck, U., Giddens, A. and Lash, S. 1994. Reflexive Modernization Politics, Tradition and Aesthetics in the Modern Social Order. CA: Stanford University Press.

Bhati, S.S., De Zoysa, A. 2013. "Stages of trust development in banking relationship." Banks and Bank Systems 8(1): 36-44.

Boyle, R., Bonacich, P. 1970. "The development of trust and mistrust in mixed-motives games." Sociometry 33: 123-139.

Brányi, Á., Józsa, L. 2015. "The role of social capital in the transdanubian winery networks." Journal of Economics \& Management 19(1): 78-94.

Brock, G. 1998. "Rethinking Feminist Ethics: Care, Trust and Empathy." Social Theory \& Practice 25(3): 531-537.

Bromiley, P., Cummings, L.L. 1995. "Transaction costs in organisations with trust." Pp. 219-247 in Research and Negotiations in Organizations, Vol. 5, edited by R. Bies, R. Lewicki and B. Sheppard. Greenwich: JAI Press.

Buta, S. 2016. "The Social Capital: From Macro to Mickroeconomic." UsV Annals of Economics \& Public Administration 16(1): 138-144.

Chan, K.S. 2007. "Trade, Social Values, and the Generalized Trust." Southern Economic Journal 73(3): 733-753.

Coleman, J.S., Fararo T.J. 1992. Rational choice theory: advocacy and critique. Newbury Park: Sage Publications.

Ding, May-Ching, Ho, Ching Wei, Lii, Yuan-Shuh. 2016. "What Men and Women Really Want: Differences in Gender-Based Evaluations of Service Recovery Efforts." Journal of Asia-Pacific Business 17(1): 59-80.

Edelman Trust Barometer. 2014. "European Results". Retrieved October 16, 2017 (https:// www.edelman.be/wp-content/uploads/2014/o1/2014-Trust-Barometer-EuropeFINAL.pdf). 
Fukuyama, F. 1996. Trust: The Social Virtues and The Creation of Prosperity. New York: Free Press.

Fukuyama, F. 2003. "Kapitał społeczny." Pp. 169-187 in Kultura ma znaczenie: Jak wartości wptywają na rozwój spoteczeństw, edited by L.E. Harrison, S.P. Huntington. Poznań: Wydawnictwo Zysk i S-ka.

Giddens, E. 2003. Ustroenie obshhestva: Ocherk teorii strukturatsii. Moscov: Akademicheskiy proekt.

Goold, S.D., Fessler, D., Moyer, C.A. 2006. "A Measure of Trust in Insurers." Health Services Research 41(1): $5^{8-78 .}$

GUS 2017. "Polska - wskaźniki makroekonomiczne." Retrieved December 22, 2017 (http://stat.gov.pl/wskazniki-makroekonomiczne).

Hardin, R. 2002. Trust and Trustworthiness. New York: Russell Sage Foundation.

Hosking, G. 2012. "Structures of Trust: Britain And Russia Compared." Pp. 32-68 in Trust: Comparative Perspectives, edited by M. Sasaki, R.M. Marsh. Boston: Brill. Leiden.

Kaźmierczyk, J. 2011. Technologiczne i spoteczno-ekonomiczne determinanty zatrudnienia w sektorze bankowym w Polsce. Warszawa: CeDeWu.

Knack, S., Keefer, P. 1997. "Does Social Capital Have an Economic Payoff? A CrossCountry Investigation.” Quarterly Journal of Economics 112(4): 1251-1288.

Koshkin, P., Zubacheva, K. 2016. "With fall of ruble, Russia's economy trying to find a new bottom" Retrieved January 12, 2016 (http://www.russia-direct.org/debates/ fall-ruble-russias-economy-trying-find-new-bottom).

Kramer, R.M. 2010. "Collective Trust within Organizations: Conceptual Foundations and Empirical Insights." Corporate Reputation Review 13(2): 82-97.

Kramer, R.M., Brewer, M.B. and Hanna, B. 1996. "Collective trust and collective action in organisations: The decision to trust as a social decision." Pp. 216-246 in Trust in Organisations, edited by R.M. Kramer and T.R. Tyler. Thousand Oaks: Sage Publications.

Lane, C. and Bachmann, R. 1998. Trust within and between Organizations: Conceptual Issues and Empirical Applications. New York: Oxford University Press.

Lane, J. 2013. "Woodcock v Cumbria Primary Care Trust: The Objective Justification Test for Age Discrimination." Modern Law Review 76(1): 146-157.

Latusek, D., Cook, K.S. 2012. "Trust in Transitions", Kyklos 65(4):512-525.

Lewicki, R.J. and Bunker, B.B. 1995. "Trust in relationships: A model of trust development and decline" Pp. 133-173 in Conflict, Cooperation, and Justice, edited by B.B. Bunker and J.Z. Rubin. San Francisco: Jossey Bass.

Lewicki, R.J., Tomlinson, E.C., Gillespie, N. 2006. "Models of interpersonal trust development: Theoretical approaches, empirical evidence and future directions." Journal of Management 32: 991-1022.

Luhmann, N. 2012. Introduction to Systems Theory, Cambridge: Polity. 
Markets Insider. 2016. "Here's how Russia survived low oil prices in 2016" Retrieved January 11, 2017 (http://markets.businessinsider.com/commodities/news/Here-s-how -Russia-survived-low-oil-prices-in-2016-1001658734).

McClellan, J.L. 2014. "Developing trusting relationships in academic advising: A review of the literature with recommendations for practices." Academic Advising J. Retrieved November 13, 2017 (https://dus.psu.edu/mentor/2014/11/developing-trusting-relation ships-academic-advising-lit-review/).

Mianowska, E. 2017. "Jak być szczęśliwym i mieć udane życie? Warunki udanego, szczęśliwego życia w opiniach studiujących i niestudiujących młodych Polaków." Pp. 59-76 in Dyskursy mtodych andragogów, edited by M. Olejarz. Zielona Góra: Uniwersytet Zielonogórski.

Noddings, N. 2012. "The caring relation in teaching." Oxford Review of Education 38(6): 771-781.

Nysten-Haarala, S. 2013. "Creating trust in institutions in Russian forest localities." Forest Policy and Economics 31: 12-19.

O'Neill P., Sevastos, P. 2013. “The Development and Validation of a New Multidimensional Job Insecurity Measure (JIM), An Inductive Methodology." Journal of Occupational Health Psychology 18(3): 338-349.

Okello, D.R.O., Gilson, L. 2015. "Exploring the influence of trust relationships on motivation in the health sector: a systematic review." Human Resources for Health 13(1): 1-18.

Perry, R.W., Mankin, L.D. 2007. "Organizational Trust, Trust in the Chief Executive and Work Satisfaction." Public Personnel Management 36(2): 165-179.

Putnam, R.D., Leonardi, R. and Nanetti, R.Y. 1993. Making Democracy Work: Civic Traditions in Modern Italy. Princeton: Princeton University Press.

Radaev, V.V. 2005. "Informal Institutional Arrangements and Tax Evasion in the Russian Economy." Pp. 119-142 in Networks, Trust and Social Capital: Theoretical and empirical investigations from Europe, edited by S.M. Koniordos. Aldershot: Ashgate.

Sasaki, M., Latov, Y.U., Romashkina, G., Davydenko, V. 2010. "Doverie v sovremennoj Rossii (komparativistskij podkhod k «sotsial'nym dobrodetelyam»)." Voprosy Ehkonomiki 2: 83-102.

Sasaki, M., Marsh, R.M. 2012. "Introduction." P. 3 in Trust: Comparative Perspectives, edited by M. Sasaki, R.M. Marsh. Leiden. Boston: Brill.

Seligman, A.B. 1997. The Problem of Trust. Princeton. N.J.: Princeton University Press. Sermat, Velio and Michael.

Sheresheva, M.Y., Berezka, S.M., Yakuba, K.S. 2016. "Vosprinimaemaya tsennost' gostinichnykh uslug klassa lyuks i loyal'nost' klientov." Marketing i marketingovye issledovaniya 3: 184-197. 
Sora, B., De Cuyper, N., Caballer, A., Peiró, J.M., De Witte, H. 2013. "Outcomes of Job Insecurity Climate: The Role of Climate Strength." Applied Psychology: An International Review 62(3): 382-405.

Sztompka, P. 2012. Doverie - osnova obshhestva. Moscov: Logos.

Taškar, Beloglavec, S., Šebjan, U. 2015. "Is Trust in Banks in Slovenia Put to the Test?" Our Economy (Nase Gospodarstvo) 61(3): 41-50.

Thomas, G.F., Zolin, R., Hartman, J.L. 20og. "The Central Role of Communication in Developing Trust on Employee Involvement." Journal of Business Communication 46(3): 287-310. DOI: 10.1177/0021943609333522.

VCIOM 2017. Putin leads the list of trust of Russian citizens to politicians. The poll of VCIOM at the end of October 2017. Retrieved November 2, 2017 (https://regnum.ru/ news/2341238.html).

Wciórka, B. 2008. Zaufanie spoteczne w latach 2002-2008 (Social trust in 2002-2008). Warsaw: Public Opinion Research Center.

White, A. 2014. "Polish Return and Double Return Migration." Europe-Asia Studies 66(1): 25-49.

White, T.I. 1998. "Sexual Harassment: Trust and the Ethic of Care." Business \& Society Review (o0453609) 100/101: 9-20.

Wieczorek-Szymańska, A. 2016, "The core competence of banks in the process of competitive advantage creation.” Pp. 161-171 in Biznes-strategï: zbirnikkejsiv [Business strategies: cases], edited by O.F. Mihajlenko. Kyiv: KNEU.

Wyrwa, J. 2014. "Zaufanie jako element partnerstwa i współpracy międzysektorowej." Pp. 20-38 in Partnerstwo międzysektorowe $w$ systemie lokalnego bezpieczeństwa społecznego, edited by A. Łoś-Tomiak. Zielona Góra: Wydawnictwo Majus.

Yıldız, M.L., Bürüngüz, H.C. 2013. "A Path Analysis of the Role of Communication in Developing Trust and Its Effects on Employee Involvement." Anadolu University Journal of Social Sciences 13(4): 63-75.

Zucker, L.G. 1986. "Production of trust: Institutional sources of economic structure, 1840-1920." Pp. 53-111 in Research in Organizational Behavior, edited by B.M. Staw and L.L. Cummings. Greenwitch, CT: Jai Press. 